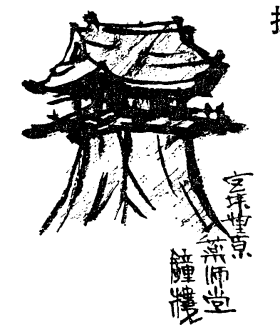

1. まえがき

深絞り性ならびにその試験法に関する諭議は。すでに 数十年の歴史を経ている.そしてこの諭議は, 自動車工 業ならびに電気機器工業の多量生産技術としてプレス加 工が重要な役割を持つてくるにつれて, 新しいあるいは 末解決な問題として絽返されてきた。すなわち，1912 年 にェリクセンカッピングテストが現われてから，その方 法による材料選別の結果とプレス作業結果の一致, ある いは不一致関する事実とそれについての諭議が，深絞 り性と樑絞り性試験法についての論議の出発で, 歴史の 始まりでもある。

1920１930年にか村て，薄板の深絞りに関する基碟的 研究が始まり, 最近まで多くの個人的な研究成果が蓄 積されてきた。また，対象とする研究が，製造技術ひい ては，製造原価の経済性に值接結びっくため，同一国内 の研究者相互ならびに研究者之業界の共同研究が，個人 的基礎研究と併行して組織化されて進められてきた。

1957 年化英国とスエーデンが 中心となつて International Deep Drawing Research Group (I.D.D.R.G.) の結成が発議され，日本も含む 8 力国が正式加盟し，国 際的共同研究を行なつている. 現在この団体は基礎, 試 験ならびに材料の研究分科会を設けて活動して和り, 1962 月 5 月 23 日, 24 日には Düsseldorf で第 3 回大会 が開催され, 各国の研究発表, 討論ならびに今後の活動 方針の討議が行なわれる、日本では薄鋼板のプレス成形 と試験法研究会が I.D.D.R.G.との連絡ならびに其同 研究に当つていて, 第 2 回大会(パリーで開催)につづい て今回も多数の関係者の出席が予定されている。

\section{2. 深絞り, 深絞り性ならびに試験法の} 基本的必要条件

深絞り性試験法を諭ずるまえに, 樑総りならびに深絞 り性について検討せ齐ばならない。樑絞りといらプレス 成形法汇対する認識の不足が, 時代が移り, 成形形状, 成形法が変るにつれて深絞り性試駼法を新しいもの, 两 るいは多くの末解決事項が含をれた閔題とした原因であ る。

一般にプレス成形は第 1 図のごとき, 板の表面沉沿5

\footnotetext{
* 東京大学教授, 航空研究所長

*** 理化学研究所塑性加工研完室
}

方向に縮む変形と伸び変形ならびに曲げ変形の 3 種の基 本的変形から成つている(1). そしてこ机ら変形の限界を

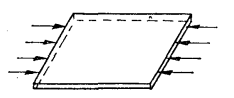

䑿みフランジ受形

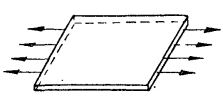

伸ばフランジ受形

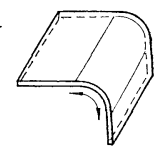

曲げ変形
第1図プレス成形に括惊る基本的変形

支配する破断は，基本的には引張破断である。乙の破断 は, 成形力負担能力の限界からくる破断 ( $\alpha$ 破断) と引張 変形限界からくる破断( $\beta$ 破断) ならびに曲げ破断の 3 種 浭宜的にわけられる，プレス成形とはこれら 3 種の変 形を単独あるいは組合わして所望形状に成形し，3種の 破断のいずれかで成形限が定まる，プレスによる成形加 工法である.

例えば，普通よく知られている第 2 図のごとき円简容

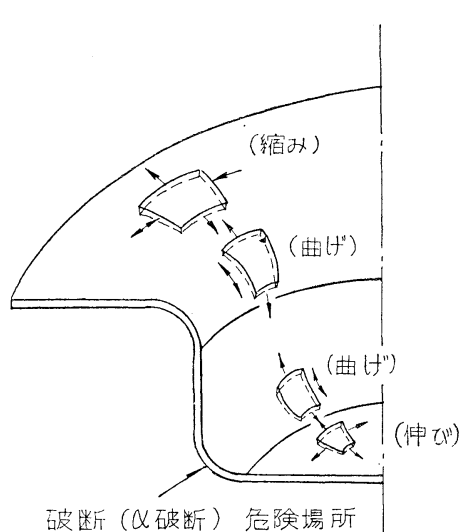

第2図円筒深絞りに掉りる 各種変形 てみる。この場合 にも 3 種の変形全 部が成形に奇与す る。しかし，深絞 りの目的が深い容 器をうることであ るので，そのため にもつとも主体と なる変形は縮みフ ランジ変形であ る。曲於変形は平 板加与立体的形状 をうるためには，
器の深絞りを考え

あらゆる場合に必要な変形要素である。しかし，曲げ半 径が板愿の数倍以上あれば曲げによる破断は起らず，か つ曲げに要する力は他の変形に要する力に比べて無視し ろるほど小さい，ポンチ底部では半径方向と円周力向の 2 軸伸び変形（伸びフランジ変形の一種）が生ずる。こ の変形が絞り深さに怙上ぼす寄与は，縮みフランジ部の 変形にくらべて非常に小さい、これら変形偠するポン チ力は, 容器底部值部でうけ持たれ, この部分の見掛上

（1）吉目：科学研究所報告, 34 (1958), 66; 理化学研 究所報告, 35 (1959), 799 . 
の応力が近似的に材料の抗張力に等しくなると破断 $(\alpha$ 破断)する。結局, 曲型的な深絞りは, 主として縮みフ ランジ変形を利用して所望の深さを得る成形法で, 成形 限は $\alpha$ 破断で定まる。

このように成形に主として利用する前述の 3 種の変形 と，その変形を支配する破断を組合わせるとプレス成形 は第1表のように区分される。そしてそれら各成形に対 する材料の成形能力，すなわら成形性が考兄られねばな らない、第 1 表に示した各種成形と成形性は基本的なる ので, 実際的にはこれら成形が組合わさつた複合成形が あり,それに対応して複合成形性も考えねばならない。

第 1 表 プレス成形と成形性の区分

\begin{tabular}{|c|c|c|c|}
\hline 破断 変开 & 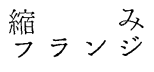 & 伸び フランジ & 曲 げ \\
\hline$\alpha$ 破 断 & $\begin{array}{l}\text { 深絞り成形 } \\
\text { (深絞り性) }\end{array}$ & 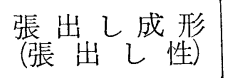 & \\
\hline$\beta$ 破 断 & & $\left|\begin{array}{l}\text { 伸びフランジ成形 } \\
(\text { 伸びフランジ性) }\end{array}\right|$ & \\
\hline 曲げ 破断 & & & $\begin{array}{l}\text { 曲げ成形 } \\
\text { (曲げ性) }\end{array}$ \\
\hline
\end{tabular}

ここでは主題が深絞りと深絞り性であるので，この主 題の範囲内に限定して，複合成形性を論ずることにす る、さらに害際作業にすつとも多い成形例である深絞り と張出しの複合成形に限る。他の成形, 例えば, 曲げな らびに伸びフランジ成形と深絞りとの複合成形はとくに 述べない。しかし，これら複合成形についても，ここで のベると同じ考え方で検討すればよいことに変わりな い.

複合成形の典型的な場合を考えると, 第 3 図 $A$ のごと く深絞りに含まれる張出し部が小さく, そして深絞り部 の破断危険個所から遠くて, この張出しが深絞り成形限 に何らの影響もあたえない場合と, Bのごとく張出し部 が深絞り限に影響を拈よぼす場合がある。すなわち, 深 絞りと張出しが組合わさる場合でも, 前者のごとく距離 的に独立の場合と重合の場合がある, A図の場合でも張

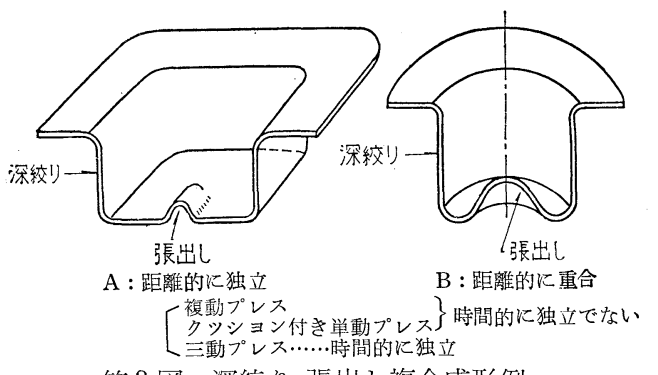

第3 図深絞り一張出し複合成形例

出し部が破断危険個所に近いと距離的な独立性はなくな り, 距離的に重合的複合成形となる.
距離的重合の複合成形の場合，時間的要素も考えねば ならない。すなわち，例えば第 3 図B図のごとき形状を する場合，三動のプレスで行なえば深絞りと張出しは独 立の行程で行なわれ時間的に独立である.しかし, 複動 式プレスあるいはクッションつき単動プレスで行なう と, 時間的に独立でない。

また, 深絞りと張出しの各くの成形度のいづれが厳し いか，あるいは両者がどの程度の割合で組合わさつてい るのか,さらに複合変形がどのような過程をたどるかな ども一応考慮することが基本的考え方であろう(2).この ような多くの因子を考㝋て, 複合成形を分類し, 複合成 形性を対応させることも, 成形性を考它る場合の基本的 立場であろう。

成形性試験方法はこれらの変形上の諸因子と実際作業 条件を満足することが望ましい，したがつて，むつとも 好ましい成形性試験は，成形される製品ごとの実際のプ レス成形作業である。しかし, 実際作業を成形性試験と することは，時間的ならびに経費的に特殊な場合を除い て不可能であり論外である。そこで成形性試験として必 要な最低の条件を満たす範囲内に扔いて, 形状的にまた 寸法的に模型化することが考学られる. 形状的には横断 面形状は円形で, 縦断面形状は第 4 図に示すごとく, 平 底, 球底, だ円底, 逆底など種々考えられる. 寸法的に

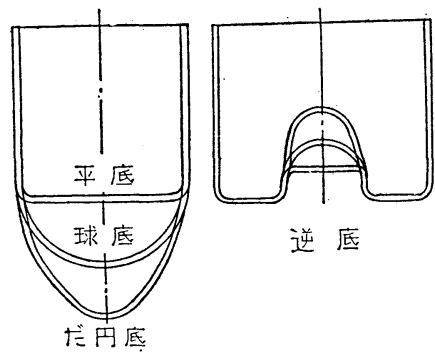

第4 図 模型化した断面形状の 種類
は普通, 横断面直 径が $100 \mathrm{~mm}$ 以下 で, 多くの場合 50 $\mathrm{mm}$ 以下に考它ら れる.これら.の模 型的形状, 寸法の 成形を成形性試験 とする場合，変形 と破断の組合わせ は，対象とする製
品形状により，また場合によつては寸法により，ならび に成形法によつて変えねばならない，すなわち，縦断面 形状のいられをを利用し, 複動式あるいはクッションつき 単動式プレスの方式で成形するか, 三動式プレス方式で 行ならかは，製品ごとに検討せねばならない。

現在, 深絞りならびに他の成形性試験法として提示さ れているものを, 前述の観点から分類し, 成形性とその 試験法を対応させると第 2 表のごとくなる．これら試験 法は，いられる時間的な条件の調節はできない，時間的 条件を満足させるためには, 吉田が提示した逆底の（逆 再絞り性を利用した）成形法(3)を用うることである。

(2) 吉田, 吉井, 阿部, 福井: 理化学研究所報告, 37 (1961) ,383.

（3）吉田：塑性之加工, 2(1961)，657, 


\section{3. 深 絞り性試 験 法}

既存の試験法で純深絞り性ならびに深絞り性を含んた 成形性試験は第 2 表に示すごときものである。いわゆる
Erichsen Cupping Test は深絞りの比較試験法ではな く, 本来張出し性試験である。深絞り性の比較を行なう ため, 円筒の深絞り限界を求める必要があることは古く

第 2 表 プレス成形ならびに成形性の区分と各種試験法の対応関係

\begin{tabular}{|c|c|c|c|}
\hline & プレス成 形 & プレス成形性 & 既存のプレス成形性試験法 \\
\hline \multirow{3}{*}{$\begin{array}{l}\text { 基 } \\
\text { 礎 } \\
\text { 威 } \\
\text { 形 } \\
\text { な 基 } \\
\text { ら礎 } \\
\text { 盛 } \\
\text { に形 } \\
\text { 性 }\end{array}$} & 深絞り成形 & 深 絞 り 性 & $\begin{array}{l}\text { Erichsen Deep Drawing Cup Test (平底ポソチ使用) } \\
\text { Swift Cup-forming Test } \\
\text { Swedish Deep Drawing Test } \\
\text { 福井式コニカルカップ深絞り試験 }\end{array}$ \\
\hline & 張 出 乙 成 形 & 張 出 乙 性 & $\begin{array}{l}\text { Erichsen Cupping Test } \\
\text { Olsen Cup Test }\end{array}$ \\
\hline & 伸びフランジ成形 & 伸びフランジ性 & $\begin{array}{l}\text { Erichsen Bore Expanding Test } \\
\text { 福井-吉田の方法 }\end{array}$ \\
\hline $\begin{array}{l}\text { 複な複性 } \\
\text { 合ら合 } \\
\text { 成び成 } \\
\text { 形に形 }\end{array}$ & $\begin{array}{l}\text { 深絞り一張出し } \\
\text { 複合成形 }\end{array}$ & $\begin{array}{l}\text { 深絞り一張出し } \\
\text { 複合成形性 }\end{array}$ & $\begin{array}{l}\text { Swift Cup-forming Test (球底ならびに楕円底使用) } \\
\text { 福井式コニカルカップ深絞り試験(球底使用) } \\
\text { コニカルカプ試験 }\end{array}$ \\
\hline
\end{tabular}

第 3 表 平面ダイスと平底ポンチによる円筒深絞り試験

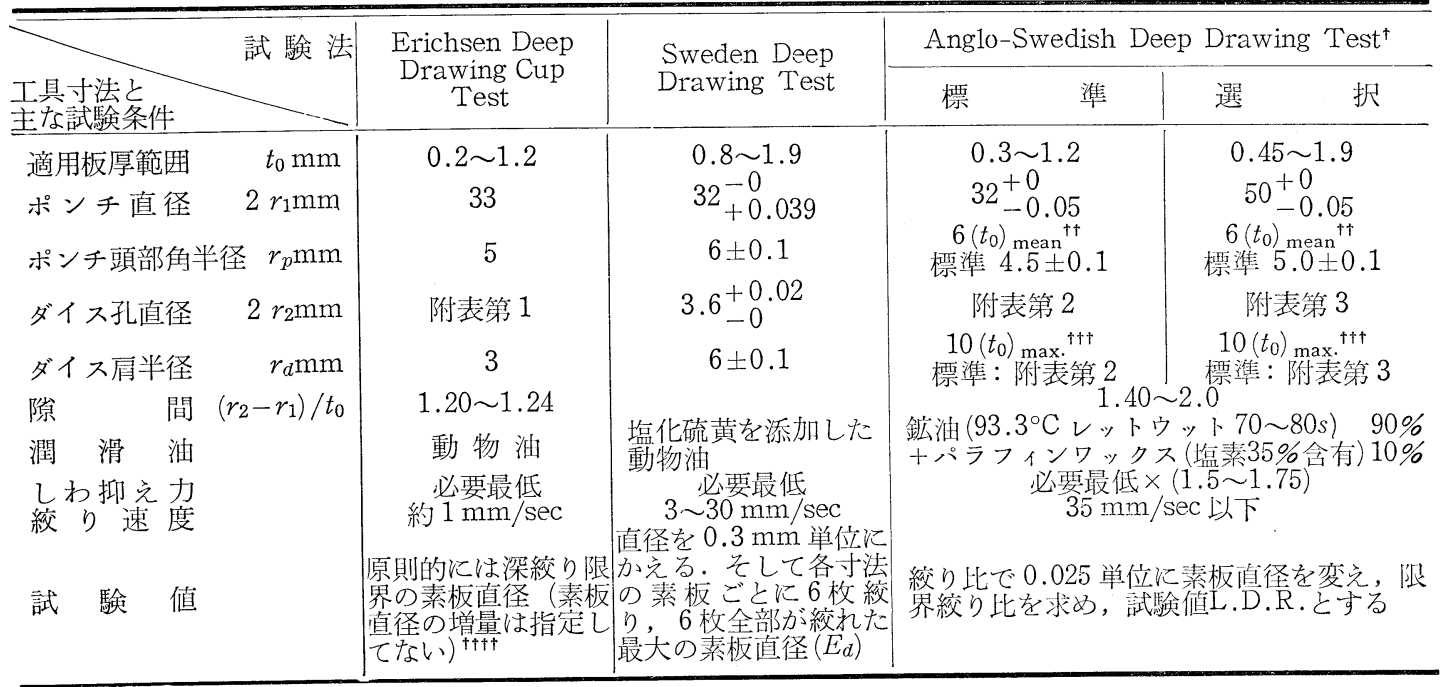

(筆者註)

†：I.D.D.R.G. 飞英国とスエーデンで共同提案を行なつた試験法で，ポンチ直径 $50 \mathrm{~mm}$ を使う方法 がいわゆる Swift Cup-forming Test である。

十： $\left(t_{0}\right)_{\text {mean }}$ 使用寸る板厚の平均厚又。

什： $\left(t_{0}\right)_{\max }$. は使用与る板厚の最大厚㕛.

十七: 試駼機には $55 \mathrm{~mm}, 64 \mathrm{~mm}, 70 \mathrm{~mm}$ の冈板打抜工具がついている。しかしこの 3 種の直径で深絞 り限界を求めても実用性は概めて少ない。試験結果に実用性をもたせるには, 直径の単位增し量を 1.0〜1.5 mm 程度にすべきと思われる。

附表第 1

\begin{tabular}{c|c}
\hline$t_{0} \mathrm{~mm}$ & $2 r_{2} \mathrm{~mm}$ \\
\hline 0.2 & 33.45 \\
0.3 & 33.65 \\
0.4 & 34.00 \\
0.5 & 34.20 \\
0.6 & 34.50 \\
0.7 & 34.70 \\
0.8 & 34.90 \\
1.0 & 35.33 \\
1.2 & 35.88 \\
\hline
\end{tabular}

附表第 2

\begin{tabular}{c|l|c}
\hline$t_{0} \mathrm{~mm}$ & \multicolumn{1}{|c|}{$2 r_{2} \mathrm{~mm}$} & $r_{d} \mathrm{~mm}$ \\
\hline $0.30 \sim 0.43$ & $33.20^{+0.05}$ & $4.3^{ \pm 0.1}$ \\
$0.43 \sim 0.61$ & 33.72 & 6.1 \\
$0.61 \sim 0.87$ & 34.44 & 8.7 \\
$0.87 \sim 1.24$ & 35.48 & 12.7 \\
\hline
\end{tabular}

附表第 3

\begin{tabular}{c|l|r}
\hline$t_{0} \mathrm{~mm}$ & \multicolumn{1}{|c|}{$2 r_{2} \mathrm{~mm}$} & $r_{d} \mathrm{~mm}$ \\
\hline $0.45 \sim 0.64$ & $51.89+0.05$ & 7.1 \\
$0.64 \sim 0.91$ & 52.56 & 9.1 \\
$0.91 \sim 1.30$ & 53.64 & 13.0 \\
$1.30 \sim 1.86$ & 55.20 & 18.0 \\
\hline
\end{tabular}


から知られていたようで，すでに第 1 次大戦の頃ドイッ では深絞り限界で鋼板を選別していたよらである。しか し，円筒の深絞り試験法は，遂現在にいたるまで公的 規格としてとり上げられていない，このことは，深絞り と張出しの関連性の究明の不足が主な原因で,ついで深 絞り限界を求める方法が Erichsen Cupping Test にく らべて著しく手間がかかることにも原因があつたと思わ れる。

現在まで提案されている平面ダイスと平底ポンチを 用万る招もな試験法の工具ならび試験条件を第 3 表に 示した、これら試験の細部については一層の検討を要す る事項が残されている。たと光ば, Erichsen Deep Drawing Cup Test では試験值飞実用性をるたせるた めに, 深絞り限界を求める場合の素板直径を何ミリ括き 飞增大させるか，末炕，同一直径の素板を幾枚づつ絞つ て深絞り限界を定めるかなどの問題がある。また Sweden Deep Drawing Test(4) と Swift Cup-forming Test(5) が組合わされたるのが，Anglo-Swedish Deep Drawing Test であつて, これは I.D.D.R.G.亿標準 試験法として提案され，ま元にのべた球底，だ円底ポン チの使用なども含めた細部の検声が行なわれている。

筆者の一人の提示による福井式コニカルカップ試験(6) は第4表ならびて第 5 図のような寸法と形状の円すいダ イスを用いる。この場合, 素板の縮みフランジ部に生ず 第 4 表 福井式コニカルカップ試験工具

\begin{tabular}{|c|c|c|c|c|}
\hline 型 & $(0)$ & (I) & (II) & (III) \\
\hline 適用板厚範团 & $\begin{array}{l}0.5 \text { 以上 } \\
0.8 \text { 満 }\end{array}$ & $\begin{array}{l}0.8 \text { 以上 } \\
1.0 \text { 米満 }\end{array}$ & $\begin{array}{l}1.0 \text { 以上 } \\
1.2 \text { 以下 }\end{array}$ & $\begin{array}{l}1.2 \text { 超 } \\
1.6 \text { 以下 }\end{array}$ \\
\hline ダイス開き伤度 & 60 & 60 & 60 & 60 \\
\hline $\begin{array}{l}\text { ダイス孔值径 } \\
2 r_{2} \mathrm{~mm}\end{array}$ & 14.60 & 19.95 & 24.40 & 32.00 \\
\hline $\begin{array}{c}\text { ダイス肩半径 } \\
r_{d} \mathrm{~mm}\end{array}$ & 3.0 & 4.0 & 6.0 & 8.0 \\
\hline $\begin{array}{r}\text { ポンチ膲 } \\
2 r_{1} \mathrm{~mm}\end{array}$ & 12.70 & 17.46 & 20.64 & 26.99 \\
\hline ポンチ顗部伯半径 & $r_{1}, 3.0$ & $r_{1}, 4.0$ & $r_{1}, 6.0$ & $r_{1}, 8.0$ \\
\hline 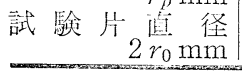 & 36 & 50 & 60 & 78 \\
\hline
\end{tabular}

工具ならびに試刽片の製作公养はとくに断わらない 限り $\pm 2 / 100 \mathrm{~mm}$ ダイ ス開学自の公差は $\pm 5 / 100^{\circ} \mathrm{C}$ 半球ポンチとしてベアリングボールを用いるとき， 精度は JIS B 1501(1956)による。

真球度综上級とする。

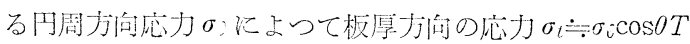

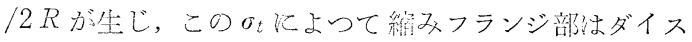

(4) O. Svehn: J. Iron \& Steel Inst., 177 (1954), 129.

(5) O.H.Kemmis: Sheet Metal Ind., 34 (1957), 203; 251.

(6) S.Fukui: Sci.Pap.IPCR 34(1938), 1442.
面へ抑えつけられる。それで適当な $\theta$ と板厚ならびに素 板直径を組合せれば，外部から特別のしわ抑えを加えな

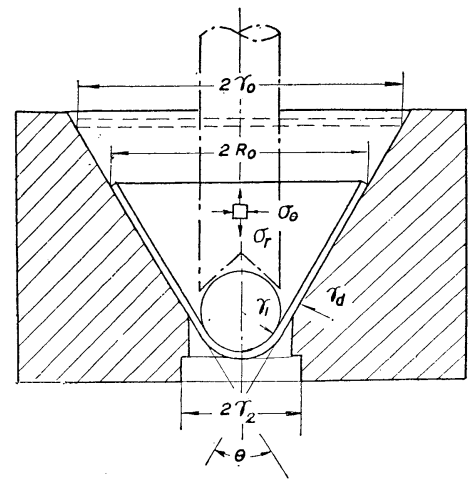

(a)コニカルカップテスト(筊り一張出し 複合成形性試験法 コニカルカップ继 $=2 R_{0}$

第 5 図 福井式コニカルカップ試験

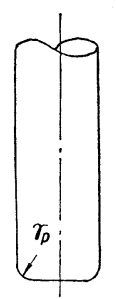

くとも，乙わを生ずることなく深絞りを行ならことがで きる。たとえば $\theta=60^{\circ}$ の場合, 素板直径は板厚の 50 ～ 70 倍程度まで, 特別なしわ抑方装置を用いないで深絞で きる。したがつて，必ず外部的しわ抑えを必要とし，そ の調節も厳密に規定されねばならない平面ダイスを用い る試験法にくらべて, 円すいダイスを用いる試験は簡便 な試験法といえる。また，ダイス肩半径の僅かな違いに よる深絞り限界の差も, 平面ダイスよりも円すいダイス を使つた方が少ない.

福井式コニカルカップ深絞り試験と呼ばれている試験 法は，このような円すいダイスと平底ポンチを用いて深 絞り限界を求める方法であつて, 第 3 表の各試験法とと むに純深絞り性試験である。これらの試験で平底ポンチ の代りに球底あるいはだ円底ポンチを用いる場合，なら びに以下にのベるコニカルカップ試験は，深絞り一張出 乙複合成形性を求める成形性試験法である。

ダイス面が平面あるいは円すい面であつても，深絞り 限界を求めることはかなりの手間を必要とする。それで 生産工場の日常業務として応用するには試験に必要な時 間の短維が重要な問題である。この問題について簀者の 2 人ら ${ }^{(7)}$ はつつの簡便法を提示しているが，その一つと して深絞り限界よりわずか大きい直径の素板を絞り，底 部が破断したときの素板外径を求めれば, 深絞り限界の 順位が判定できることを示した。この提示に基づき，第 4 表ならびに第 5 図に示した工具を用いた試験法が，い わゆるコニカルカップ試験である。この試験法は薄鋼板 のプレス成形と試験法研究会の前身であるこニカルカッ プテスト研究会で種々の検討が加えられ，以下のような 試験法基蕉が定められている。

（7）福井, 工藤, 吉田, 大川：東大理工学研究所報告, $6(1952), 351$. 


\section{4. コニカルカップ試験エ具と試験法 の 基 準}

(1) 適用範囲 $0.5 \sim 1.6 \mathrm{~mm}$ の薄鋼板のプレス成形 性試験

（2）試験工具 (i) ダイス形状と寸法(第4 表に示す). (ii) ダイスの材質と表面仕上げ. 工具鋼で焼入れ燒戻し 後の硬さが $\mathrm{H}_{\mathrm{RC}} 60$ 程度で, 仕上げは JIS 1.5〜3S を標 準とする. (iii) ポンチ形状と寸法（第4 表に示す球底ポ ンチを用いる). (iv) ポンチ先端部はベアリングボール を使用する。

（3）試験片 (i) 板厚と工具寸法(第4 表に示す)。(ii) 試験片直径 (第 4 表に示す)。(iii) 試験片製作方法. 原則 として打ち抜きにより円板を作り, 工具の精度は第 5 表 に示すものとする. (iv) 試験片のセット法, 打ち抜きバ リをポンチ側に向け，ポンチ軸に対して垂直にセットす る. (v) 試験前処理. ベンゾールなどで全面を脱脂し, \#120 マシン油を試験片両面に塗布する.

（4）試験方法 (i) 試験の要領, 規定の形状ならびに寸 法のコニカルダイスに, 定められた直径の試験片を水平 にセットし，所定形状，寸法のポンチで底が抜けるまで 第 5 表 コニカルカップ試験片打抜き工具

\begin{tabular}{c|c|c}
\hline 型 別 & ダイス直径 $(\mathrm{mm})$ & ポンチ直径 $(\mathrm{mm})$ \\
\hline (0) & $36.00 \pm 0.01$ & $35.92 \pm 0.01$ \\
(I) & $50.00 \pm 0.01$ & $49.91 \pm 0.01$ \\
(II) & $60.00 \pm 0.01$ & $59.88 \pm 0.01$ \\
(III) & $78.00 \pm 0.01$ & $77.80 \pm 0.01$ \\
\hline
\end{tabular}

されること. (iii) 試験機械 材料試験機あるいはクラン クプレスを用い, プレスの場合は $50 \mathrm{rpm}$ 程度以下のも ので,なるべく下死点近くの行程で試験を行ない, 試験 機械名を明記する。(iv) カップ径の測定 日産型カップ 径測定器を原則とし，ノギスあるいはマイクロメーター で測定した場合は測定器名を明記する。（v) 試験値の表 示 カップ外縁部外径の最大, 最小の直径の算術平均値 (mm) で表わし、 コニカルカップ值, または略して C.C.V.-X と呼ぶ(Xは型別を示す). また破断時の外径 $R_{0}$ と試験片外径 $r_{0}$ の比 $R_{0} / r_{0}$ を試験值として用いても よい.

ここに示したコニカルカップ試験では, 原則として球 底ポンチを用いていること，ならびに深絞り限界以上の 直径の試験片を用いていることによつて，その試験值は 純粋の深絞り性でなく, 張出し性を比較的多く含んだ複 合的深絞り性を示ものとなつている.

\section{5. 各種成形性試験值の関係}

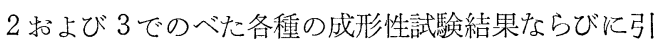
張り試験值間の相互の関係を調べるために, 19 種類のリ ムドならびにアルミキルド鋼, 純鉄, 高張力鋼を用いて 試験を行ない,それぞれの試験値間の相関係数を求めた 結果を第6 表に示した ${ }^{(8)}$. ここで, 深絞り性試験とし て提案されている。平底ポンチを用いて深絞り限界 (L.D.R.)を求めるSwift Cup-forming Test と福井式 コニカルカップ深絞り試験による試験值相互間の相関は きわめて高く, 実用的に深絞り性を求めるには, いずれ 第 6 表各種成形性試跒値間の相関係数

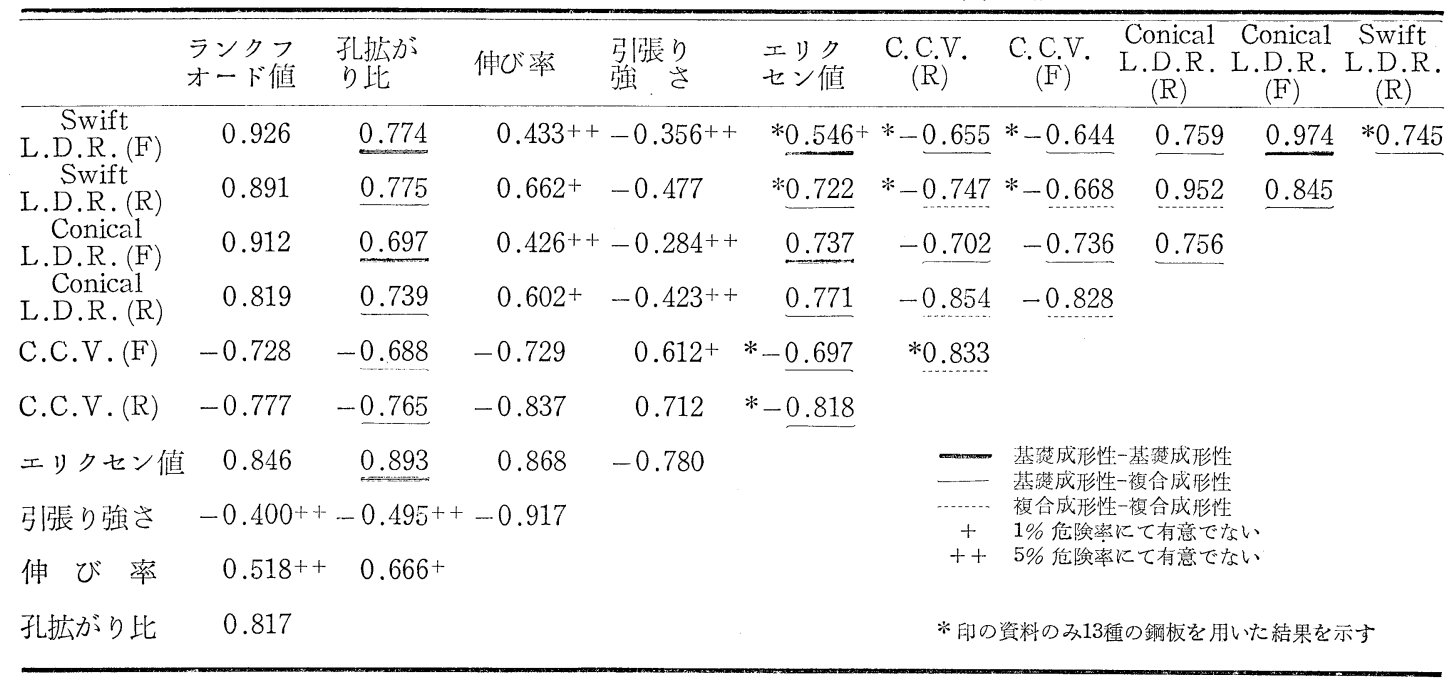

\section{（F）而底ポソチ使用を意味する (R) 球底ポンチ使用を意味する}

コニカルカップ状に成形する。底が抜けたときのカップ 上縁部外径が試験值である。(ii)工具の取りつけ。ポン チならびにダイスは原則としてダイセットに正確に保持
の方法を用いてもさしかえないといえる、深絞り性試験 值といわゆるエリクセン值として与えられる張出し性試 （8）福井, 吉田, 阿部：望性と加工, 2(1961),665. 
験值, ならびに孔拡げ試験でえられる伸びフランジ性試 験值の間では一方の試験で他を代用しうるほど高い相関 関係は認められない。したがつて, 前にものべたように， 材料の基本的なプレス成形性を求めるためには，それぞ れに応じた試験法を選ばなければならない。

深絞り性, ならびに張出し性の基礎成形性と, それら の複合成形性を示す試験値の間の相関関係を第 6 表から とり出して示すと第 6 図に示すようになる。すなわち,

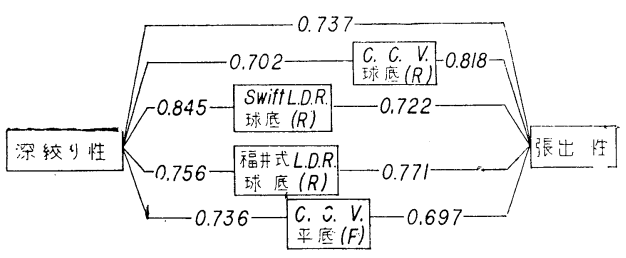

第 6 図 深絞り性と張出乙性の複合成形性と 基礎成形性の相関

球底ポンチを用いて深絞り限界を求める方法では, ポン チ頭部角の半径が増すことによつて, 張出し性が付加さ れたために, 平底ポンチによる深絞り性試験值との相関 は低くなることがわかる、いわゆるコニカルカップ試験 では深絞り限界以上の寸法の試験片を用いることで，よ り大さく張出し性が加味されて, 深絞り性試験值との相 関はさらに低下している。一方付加される張出し性の量 が增すにしたがつて, 張出し性試験値との相関は高まる 傾向が見られる。これは, 深絞りと張出し成形がそれぞ れの試験に組合わされている量的な違いによるものと考 えることができる。

引張試験值は単独では多くの場合深絞り性と関係がな く，深絞り性の尺度としては汪とんど使用できない。た だし, 引張試験に括ける試片の長さ力问ひずみ $20 \%$ の
ときの慣用幅ひずみと慣用愿さひずみの比である．ラン クフォード值 ${ }^{(9)}$ ほ, 深絞り性ならびに深絞り性を多く含 んだ複合成形性との間にかなり高度の相関が認められる ことは興味ある問題であつて, 今後検討を要するものと 思われる。

\section{6.あとがき}

ここではプレス成形，成形性ならびに成形性試験法の 相互の関連性の検討と，既存の深絞り性試験の基本的性 格を調べ，実際応用にあたつて考劣るべき幾つかの事項 を概説した。これら試験法の利用価値ならびに将来の試 験法の在り方は，プレス用材料とプレス技術の関連に抒 いて定まるものである。材料の成形性が非常によくな り，それと対応してプレス技術も完全な多量生産方式が 用いられ個々の工程の成形度が減るとすれば, むはや成 形性試験は無用のものとなる。このような状態は非常に 好ましいことであり, 各部門の大きな研究成果の集合結 果である。しかし，材料の成形能を充分に活用し，プレ ス技術に一畨の経済性をあたえるため, 成形度を一層綮 しくする力向も考えられ，この場合には成形性試験法が 材料の有効な利用と安定した作業をらるために果す役割 は依然として大きい。

成形性試験法も形状, 寸法的な面で無批判に模型化 し，その段階で䍢視した因子も少なくない，プレス成績 結果と試験值に見られるある種の不一致は，このような ところに一つの原因がないとはいえない，現在の成形性 試験法の活用だけでなく, 将来の試験法の方向を作るた めにもこれら因子の特性究明が必要であろう。

(9) W.T.Lankford, S.C.Snyder \& J.A.Bausher: Trans.ASM, 42 (1950), 1197.

\section{特 許 $\quad$ 巢 $\quad$ 報}

改良された合金 (p2) 〔特公 昭36-2553 36-4-3 優先権 主張 1958-10-21(イギリス国) イギリス国 クリストファ 一,タイザック 同所ジョン,プールトン 共同発明，イ ギリス国 ユナイテッド,キングドム,アトミック,エナー ヂイ,オーソリテイ 出願] $\mathrm{Cu}=0.125 \sim 0.5$ 原子 $\%, \mathrm{Sn}$ $=0.5$ 原子 \%を含有し残金が $\mathrm{Zr}$ 拈よび不純物より成る 合金.

製鉄製造方法 (p2) [特公 昭 36-2554 36-4-3 伊達町 石川 清 発明 千代田区 北海道砂鉄鋼業 $K K$ 出願] 鉄鉱石を石灰石, $\mathrm{Mn}$ 鉣石等の媒愹材と共に加熱熔融し た後これに 2 次的にコークス，木炭等の国体還元材起添 加して還元を行なわしめその際発生する澴元ガスそ直接 炉内で然焼させその発生熱を加熱と還元に利用する。

鉛含有鋼の製造方法 (p4) 〔特公 昭36-2555 36-4-3 優
先権主張 1958-6-28(アメリカ国) アメリカ国ミカエル テネンバウム同国, ジェームス ダブリューハーイ 同 国 フランク，ダブリュールユーアセン 共同発明, 同国 インランド スティールコムパニー 出願】熔融鉛浴に 熔鋼を供給し，沈降によつて熔鋼と熔鉛とを二層に分離 し, 少量の鉛を含む鋼より成る上層を取出し, 凝固させ ることによつて含鉛鋼を製造する。

異質の金属電極を組合わせ使用して合金鋼を製造する 方法 (p1) [特公 昭36-2556 36-4-3 文京区 堀居太郎 発 明出願】金属電極を使用する電気炉に抮いて，異質の 金属電極を $2 \sim 3$ 種組合わせて用い, 各電極の溶け込久 量を調節しつつ，成分調整を行な弓。

連続熔融メッキ装置 (p2)〔特公 昭36-2557 36-4-3 名 古屋市 金田政光同市 KK 興和工業所 共同発明 千代 田区日立金属工業 $K K$ 出願】 チェンュンベヤーの吊 汗に吊した被メッキ材料を順次メッキ槽内に塖入して取 出す. 